DOI: 10.15503/onis2011-49-55

\title{
„WOJNA TO CIAŁO ALE WYWRÓCONE...". \\ POSZUKIWANIE TOŻSAMOŚCI W POWOJENNYM ŚWIECIE NA PRZYKŁADZIE \\ CYKLU Utworów La Guerre trouvée JeAn-Pierre FAye'a oraz tomu Hermes, pies i gWiazda Zbigniewa Herberta
}

\author{
Karolina SaEdecka \\ k.saldecka@gmail.com
}

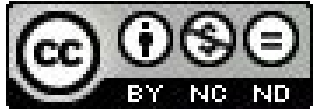

Proponowane w niniejszym szkicu zestawienie twórczości polskiego i francuskiego autora ogranicza się do ukazania i przybliżenia zagadnienia odnajdywania tożsamości w powojennej rzeczywistości. Dwa odrębne, całkowicie odmienne doświadczenia wydają się pozornie na tyle odległe, oddzielone faktami, że nie sposób uczynić z nich doświadczeń zbieżnych. Niemniej jednak poetyckie widzenie wojennych przeżyć, starań o przetrwanie w świecie niespodziewanie „wywróconym", ze zmienionymi wartościami, danymi nagle, á l'envers, zdaje się zbliżać obu autorów.

Twórczość Jean-Pierre Faye'a, prozaika i poety urodzonego w 1925 r., jest znana w Polsce głównie dzięki przekładom Krystyny Rodowskiej. Polska tłumaczka omawia pokrótce literacką sylwetkę Faye'a w antologii Na szali znaków $w^{1}$, jednak twórczość francuskiego autora pozostaje w Polsce tematem niezbadanym. Wybór omawianych w niniejszym tekście utworów nie był łatwą kwestią. Ostatecznie jednak badane teksty obu poetów stanowią najbardziej reprezentatywne przykłady, zarówno pod względem językowego ukształtowania, jak i zawartego w nich znaczeniowego ładunku.

W utworze o incipicie [wojna to ciało ale wywrócone] Faye koncentruje się przede wszystkim na wartości, jaką jest ludzkie życie. Zaakcentowanie cielesności w wierszu francuskiego poety oddziałuje na czytelnika i nie pozwala zapomnieć także o sferze duchowej, psychicznej, umęczonej niepokojem, niepewnością i strachem wywołanym przez wojenne działania. Warto zwrócić uwagę na fakt, iż twórczość Jean-Pierre Faye'a od zawsze napiętnowana była przez wojnę. Rodowska podaje, że Faye zadebiutował nieformalnie już w wieku czternastu lat utworem napisanym 3. września $1939 \mathrm{r}$. Wiersz był reakcją na wiadomość o ataku armii hitlerowskiej na Polskę (utwór ten znajduje się w wydanym w 1997 r. tomie La Guerre trouvée). Wspomniany tomik wierszy dotyczy jednak ściśle wojny toczaccej się na Bałkanach. Faye w La Guerre trouvée ${ }^{2}$ opowiada się po stronie masakrowanych Bośniaków. Omawiany tekst eksponuje przede wszystkim rolę i znaczenie ciała w ludzkiej egzystencji:

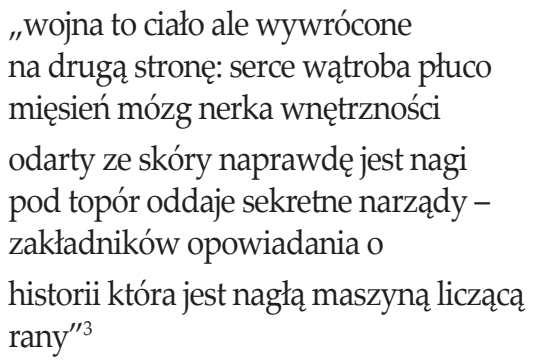

K. Rodowska, Na szali znaków. Czternastu poetów francuskich, Wrocław 2007. Wszystkie cytaty z utworów JeanPierre Faye'a pochodzą z tego wydania.

2 Zbiór wierszy Jean- Pierre Fayéa nie doczekał się jeszcze pełnego tłumaczenia na język polski. Tytuł można przełożyć jako Odczuwanie wojny.

3 Tamże, s. 86. 
Faye poprzez zastosowaną enumerację kolejnych narządów zyskuje określony semantyczny efekt. Obraz ludzkiego ciała ukazany á rebours wywołuje u odbiorcy nie tylko niepokój, lecz zaskoczenie i przerażenie jednocześnie. Pierwszy wers utworu nie zapowiada bowiem znaczącej zmiany perspektywy postrzegania ciała. „Wojna to ciało ale wywrócone" - pisze Faye, jednak obecna dalej przerzutnia przemienia i konkretyzuje jedynie sugerowany $\mathrm{w}$ pierwszym wersie utworu zaburzony porządek zjawisk. Dopiero wyrażenie przyimkowe „na drugą stronę” daje nam nową wizję. Jest to widok ciała "wywróconego", lecz wnętrznościami na zewnątrz po to, aby uczynić je widocznymi, zarysować i uchwycić sekretne ruchy narządów, tkanek, mięśni, krwi, a jednocześnie po to, by w wyobraźni odbiorców objawiła się prawda o niszczącej sile wojny, okrucieństwie, bólu, który powoduje zachwianie światem.

Pozostawienie jako przedmiotu rozważań ludzkiego ciała ukazanego w sposób kontrowersyjny, budzący zdziwienie, przerażenie, być może niesmak pozwala także na otwarcie przestrzeni dialogu pomiędzy problemem człowieczeństwa pojmowanego w wymiarze duchowym i fizycznym oraz „, historią która jest nagłą maszyną licząca/rany”. Fraza zastosowana przez Jean-Pierre Faye'a niesie bowiem ładunek znaczeniowy i emocjonalny. Historię nazwaną „"maszyną liczącą rany" określa przymiotnik "nagła” (polski umiarkowany odpowiednik silniejszych, nasyconych znaczeniowo leksemów: soudain, brusque, inattendu, véhément, impétueux $)^{4}$, co podkreśla jedynie nieprzewidywalny charakter, gwałtowność historii determinującej los człowieka.

Podczas analizy utworu Jean-Pierre Faye'a nasuwa się pytanie o filozoficzną naturę refleksji prowadzonej w La Guerre trouvée. Faye jako wykładowca filozofii na Sorbonie, członek Centre National des Recherches Scientifiques (Państwowego Ośrodka Badań Naukowych), prywatnie znawca poglądów Fryderyka Nietzschego, w niemal wszystkich swoich dziełach, poetyckich i prozatorskich, zawiera elementy filozoficznego dyskursu. Począwszy od wydanej w 1972 r. pracy Les Langages totalitaires ${ }^{5}$, gdzie analizuje mechanizmy powstawania i kształtowania języków ideologii oraz władzy, Faye buduje teorie, iż ,jęzzyk, struktury narracyjne nie tyle opisuja, co wpływają na rzeczywistość i generują przebieg historii"'6. Znaczenie wpływu języka na budowanie wizji rzeczywistości w systemach totalitarnych jest dla autora La Guerre trouvée mechanizmem służącym manipulacji i propagandzie. W publikacji zatytułowanej La déraison antisémite et son langage (1993), Faye wydaje się podtrzymywać wysuniętą w 1972 r. tezę, dlatego też nie sposób nie dostrzec określonego nurtu filozoficznego w wydanych w późniejszych latach powieściach i zbiorach wierszy8.

W omawianym utworze Faye’a widać także niezwykłą dbałość o język. W drugiej całostce utworu pojawia się bowiem fraza przywodząca na myśl kilka skorelowanych semantycznie obrazów. Poeta za pomocą trzech wersów otwiera pole semantyczne związane z wojna, śledztwem, procesem, sądem. Taka siatka pojęć powstaje przede wszystkim za sprawą konstrukcji "oddawać pod topór", „,odrzeć ze skóry” oraz dzięki leksemowi „zakładnicy”. W wykreowanej w taki sposób sytuacji lirycznej człowiek staje się zniewolony przez dziejowe wydarzenie, zostaje „zakładnikiem historii". Oddaje swoje ciało, ,sekretne narządy” to jednak nie tylko somatyczna sfera człowieczego istnienia, lecz również duchowe istnienie, tożsamość. Wizja cielesnego wymiaru człowieczeństwa nakreślona została w wierszu także nieco synestezyjnie, co daje

\footnotetext{
4 Pomijam kwestie związane z przekładem utworu Faye'a, autorstwa Krystyny Rodowskiej, gdyż wymagają one rozbudowanej analizy.

5 Praca nie jest dostępna w języku polskim. Tytuł tłumaczę jako Języki totalitaryzmu.

$6 \quad$ K. Rodowska, dz. cyt., s. 384.

Tytuł tłumaczę jako Niedorzeczność antysemityzmu i jego języka.

S Jean- Pierre Faye angażuje się do tej pory w tworzenie refleksji politycznej nie tylko za pomocą poezji bądź prozy. Świadczy o tym jeden z jego nowych esejów z pogranicza literatury i polityki: La bulle, le cycle, l'avenir (Kula, obieg, przyszłość) opublikowany na stronie internetowej: http://www.zonesdattraction.org/spip.php?article27, 19.03.2011.
} 
wrażenie pewnej polisemii percepcyjnej. Mimo że leksemy znajdujące się w tekście odnoszą się niemal wyłącznie do zmysłu wzroku, wyobraźnia sugeruje przecinanie się modalności percepcyjnych ${ }^{9}$ takich, jak: kolor, zapach, dźwięk. Wielość zmysłowych doznań sugerują leksemy: „wy-

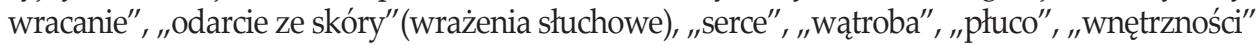
(wrażenia wzrokowe z odniesieniem do zapachu i ruchu żyjącego ciała).

Należy zatem przyznać, że Faye ukazuje w tym utworze obraz niezwykły, nieschematyczny, umieszczony w niedookreślonej perspektywie, abstrahujący od konkretu, lecz jednocześnie obfitujący w somatyczne szczegóły, nagie i krwawe. Wymiary obrazowania autora La Guerre trouvée podlegają selekcji, są jednak tylko pozornie abstrakcyjne. Łączące je związki metafor cechuje logika i stabilność, co z kolei sprawia, że czynią opis uniwersalnym i pełnym.

W utworze o incipicie [wojna to ciało...] ujawnia się pojęcie tożsamości człowieka w świecie powojennym jako rzeczywistości naznaczonej tragedia, bólem, cierpieniem, pustką. Jean-Pierre Faye bywa jednak o wiele bardziej dosłowny w poetyce szczegółu, w budowaniu lirycznych sytuacji, w których człowiek zmuszony jest do poszukiwania własnego miejsca w „wywróconym” przez wojnę świecie. Mowa tu o poszukiwaniu na własną rękę, o usilnym „zakotwiczaniu” swojego jestestwa w rzeczywistości fizykalnej, której rysy i kontury wyznaczane są przez przedmioty, meble, powtarzalność zjawisk atmosferycznych, pór dnia i roku. Z podobną sytuacją mamy do czynienia w utworze o incipicie [przycichła wojna upłynał już tydzién]:

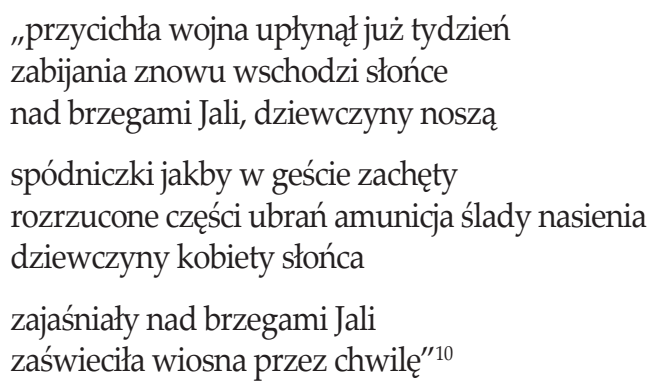

W przytoczonym powyżej utworze mamy do czynienia z wizją życia po zatrzymaniu żywiołu wojny. Przestrzeń $w$ wierszu to tereny nad brzegiem rzeki Jali ${ }^{11}$, lecz poeta tworzy przestrzeń zupełnie inna, złożoną ze szczegółów życia codziennego. Poprzez drobne zjawiska, zachowania kobiet opuszczonych przez mężów, ojców, braci, narzeczonych zaczynamy odczuwać, że choć pociski, szumy nalotów i strzelaniny ucichły, jednak pozostaje ogrom ciężaru doświadczeń, doznanych krzywd. Sylwetki kobiety i dziewcząt jaśnieją w słońcu nad brzegiem rzeki, lecz zestawienie leksemów „,spódniczki”, „amunicja”, , „Ślady nasienia" jest bezpośrednio skorelowane z ostatnim wersem utworu. Wiosna nadchodzi bowiem w myślach, w marzeniach, w migawce jasnych wspomnień z życia przed wojna, podczas gdy rzeczywistość to rozrzucone ubrania, chaos, amunicja. Dlatego też obraz nakreślony w tym utworze jest ukształtowany głównie przez emocje. Zarówno postacie, przedmioty codziennego użytku, jak i kształty, rzadziej kolory, zapachy, smaki stają się znaczeniowymi odpowiednikami emocji.

W obu omawianych utworach z tomu La Guerre trouvée doznania emocjonalne oscylują pomiędzy rozpacza, cierpieniem, niekiedy niemocą. Relacje pomiędzy tym, co wzrokowe a tym, co

\footnotetext{
9 Szerzej o zjawisku polisemicznych sensów percepcyjnych pisze W. Skrzypczak, Myśl ucieleśniona i myśl imaginacyjna. Wymiary obrazowania w języku i zasady porzadkujace, „Litteraria Copernicana” 2008, nr 2, s. 12- 14

10 J. P. Faye, [przycichła wojna uptynąt już tydzień], [w:] K. Rodowska, dz. cyt., s. 90.

11 Mowa prawdopodobnie o rzece, której nazwa w formie mianownikowej brzmi Jalu.
} 
intelektualne, wyobrażeniowe nie stanowią opozycji w poezji Faye'a. Język i wyobraźnia poety pracują jednocześnie, równomiernie, zgodnie. Czytanie tekstów francuskiego twórcy można by nazwać „,czytaniem przestrzeni” ${ }^{\prime 12}$. Mowa o przestrzeni nie tylko fizykalnego świata, lecz o przestrzeni wyobraźniowej, odrealniającej rzeczywistość, emocjonalnej.

Podobieństwo poetyckiej twórczości Jean-Pierre Faye'a oraz Zbigniewa Herberta najbardziej wyraźne wydaje się w tomie polskiego autora Hermes, pies i gwiazda, wydanym w 1957 r. Co prawda omawiane zbiory wierszy obu twórców dzieli czterdzieści lat, aczkolwiek należy pamiętać, że tomik La Guerre trouvée zawiera teksty sięgające 1939 r. oraz lat późniejszych. Ponadto w omawianym zbiorze utworów Faye'a znajdujemy o wiele więcej wojennych i powojennych obrazów niż na przykład w tomie Couleurs pliées ${ }^{13}$, wydanym w 1965 r. we Francji.

Twórczość Zbigniewa Herberta od lat jest w Polsce i na świecie przedmiotem badań nie tylko historycznoliterackich, lecz także typowo komparatystycznych ${ }^{14}$. W niniejszych rozważaniach warto poświęcić szczególną uwagę zbiorowi wierszy Hermes, pies i gwiazda, głównie ze względu na zawarte w nim utwory przywołujące kwestie tożsamości w powojennym świecie. Herbert porusza te zagadnienia w niemal wszystkich książkach poetyckich, jednak wspomniany powyżej tom w swojej wymowie, wymiarach wyobraźni oraz językowym kształcie wydaje się najbardziej odpowiednim materiałem do analizy porównawczej z tekstami Jean-Pierre Fayéa.

W nakreślonym kontekście niezwykle interesujący jest wiersz Substancja. Na utwór ten warto zwrócić uwagę przede wszystkim ze względu na silnie wyeksponowaną cielesność. Co więcej, efekt ten został osiagnięty nie tylko za pomocą otwarcia pól semantycznych związanych z ciałem, lecz głównie za pomocą słownictwa bitewnego. Wydaje się, iż nagromadzenie wyrazów przynależących do klasy obiektów, przedmiotów, zjawisk, zachowań związanych z wojna, zdobywaniem władzy niejako kategoryzuje, „porządkuje” utwór. Mowa o następujących leksemach: „proporce", „,berło”, „pożar", „ruiny”, ,zmarli/umarli”, „głodzenie”, „bicie”, , ucieczka”, „mur więzienny", "ginąć", „,naród".

Poeta skupia zatem uwagę (własną oraz potencjalnego odbiorcy tekstu) na bezmiarze nieszczęść i klęsk, jakie wywołuje wojna. Podobnie jak u Jean-Pierre Faye’a możemy dostrzec zatrzymanie refleksji na życiu codziennym tych, którzy cierpią w wyniku konfliktów zbrojnych. Najbardziej dobitnie poeta akcentuje tę prawidłowość w drugiej całostce utworu:

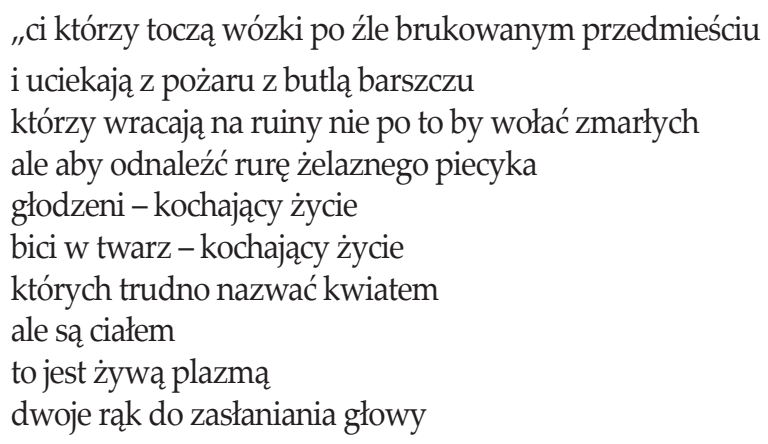

12 Termin „czytanie przestrzeni” zapożyczam od D. Korwin- Piotrowskiej, Powiedzieć świat. Kognitywna analiza tekstów literackich na przykładach, Kraków 2006, s. 29.

13 Tomik ten również nie doczekał się pełnego przekładu na język polski. Podaję propozycję przekładu tytułu: Złożoność kolorów. Szczegóły dotyczące wydania tego oraz pozostałych zbiorów wierszy Faye'a znajdują się na stronie internetowej autora: http://www.jean-pierre-faye.net/dev/?page_id=70\#poemes, 19.03.2011.

14 Odwołuję się tutaj do publikacji pod redakcją J. M. Ruszara, Dialog i spór. Zbigniew Herbert a inni poeci i eseiści, Lublin 2006. 
dwoje nóg szybkich w ucieczce

zdolność zdobywania pokarmu

zdolność oddychania

zdolność przekazywania życia pod murem więziennym" ${ }^{\prime 15}$

W abstrakcyjnej, niedookreślonej przestrzeni opisanej przez Herberta można usytuować każde państwo, naród, dowolny krajobraz. Instynkt przetrwania łączy bowiem całą ludzkość. Uniwersalność postrzeganego w poetyckiej wizji świata podkreśla także pointa wiersza, za którą można uznać całą trzecią strofę Substancji:

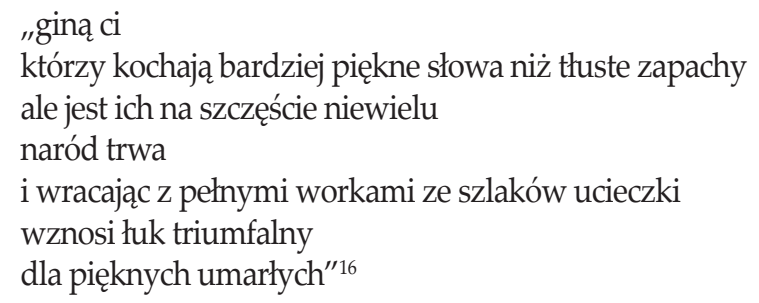

U Herberta mamy do czynienia również z problemem alienacji. Jest to rodzaj wyobcowania podobny do tego, który prezentuje Jean-Pierre Faye. Herbert jednak eksponuje wyobcowanie poprzez metaforę odmienności, braku porozumienia z otoczeniem złożonym z „,tych którzy kochają tłuste zapachy", dlatego też osoba mówiąca w większości utworów z tomu Hermes, pies i gwiazzda walczy o „oswajanie przedmiotów", wielbi ich skończoność, dziwi się ich prostocie, doskonałości (Jedwab duszy, Pokój umeblowany, Biały kamień). Wydaje się, że to samo czyni Faye przyglądając się rzeczywistości, przestrzeni, przedmiotom, pojmując i tym samym będąc pewnym - jak określa to Radosław Sioma - „ich egzystencjalnej (ontycznej właśnie) samoistności i wyjątkowości”i"17.

Co więcej, Jean-Pierre Faye nieustannie „dziwi się” tajemnicy ontologicznej ludzkiego ciała. Somatyczna sfera życia człowieka jest u Fayéa pod stałą obserwacją, kontrolowaną przez czujne spojrzenie jak gdyby siła wzroku obserwatora potwierdzała bądź też miała uwiarygodnić istnienie ciała, jego realność, zasadność istnienia w powojennym świecie (w utworach o incipitach [wieje groza i śmiercia], [żaden dzień nie jest tak niebezpieczny], [I Minka opowiada: kiedyś]).

W świetle powyższych rozważań istotne podobieństwa w twórczości obu autorów rysują się także w płaszczyźnie języka. Frazy Herberta są zdyscyplinowane, niekiedy ascetyczne, lecz jednocześnie pełne przemyślanych anafor, przerzutni, stylizacji, przemian perspektyw (Jak nas uprowadzono, Pan od przyrody). Prostota Herbertowskiego języka uderza szczególnie w utworze Kołatka, gdzie dystans i ironia służą ponownemu definiowaniu życiowej funkcji osoby mówiącej w wierszu:

„moja wyobraźnia

to kawałek deski

a za cały instrument

mam drewniany patyk"18

15 Z. Herbert, Hermes, pies i gwiazda, [w:] tenże, Poezje, Warszawa 1998, s. 154; wszystkie cytowane fragmenty utworów Zbigniewa Herberta pochodzą z tego wydania.

16 Tamże, s. 154- 155.

17 R. Sioma, Skończoność przedmiotów i niegotowość człowieka, [w:] J. M. Ruszar (red.), dz. cyt., s. 70.

18 Z. Herbert, Kołatka, [w:] tenże, dz. cyt., s. 100. 
Powyższe frazy eksponują konieczność odnalezienia narzędzi do poszukiwania prawdy w świecie dotkniętym wojennym doświadczeniem. Narzędziami tymi są rozum i język. Andrzej Kaliszewski określa specyfikę poezji Herberta jako „łączenie awangardy z tradycja, a wyobraźni dyktatorskiej z wyobraźnią relacjonująca, z etyka, moralistyka, co było założeniem starszych poetyk, zwłaszcza klasycznych [...] Herbert potrafi przy tym być dowcipny, ironiczny, przewrotny, kontrowersyjny i jednocześnie dla nawiązania autentycznego dialogu z czytelnikiem, jak i podlegającą dehumanizacji współczesnością, on - erudyta i filozof, sięga po język ulicy i kultury masowej, przy jego pomocy przemawia o sprawach najważniejszych" ${ }^{\prime 19}$.

Trudno polemizować z opinią Kaliszewskiego. Poezja Herberta jest bowiem naznaczona wyjątkową dbałością o właściwości poetyckiego języka takie, jak: znaczenie, emocjonalny „ciężar" słowa. Co więcej, analiza poezji Jean-Pierre Faye'a z tomu La Guerre trouvée pozwala odnaleźć podobną zasadę porządkującą kształt frazy w utworach francuskiego twórcy. Faye - filozof, eseista, erudyta - również dąży do uzyskania prostoty, precyzji budowanych zdań (co potrafi rozpoznać początkujący tłumacz literatury francuskiej podczas analizy oryginalnych tekstów).

Powyższe ustalenia dotyczące roli cielesnego i duchowego wymiaru człowieczeństwa w poszukiwaniu tożsamości w powojennym świecie nie mają charakteru ostatecznych ustaleń, rozstrzygnięć. Pominięto bowiem wiele istotnych kwestii związanych choćby z przekładami utworów francuskiego twórcy. Brakuje także szczegółowych rozważań dotyczących wymiarów obrazowania w twórczości obu autorów. Niemniej jednak ten krótki szkic może stanowić punkt wyjścia dla późniejszych, dokładnych badań.

\section{Bibliografia}

Herbert Z., Poezje, Warszawa 1998.

Kaliszewski A., Zbigniew Herbert, [w:] Skoczek A. (red.) Literatura wspótczesna, Warszawa 2008.

Korwin-Piotrowska D., Powiedzieć świat. Kognitywna analiza tekstów literackich na przykładach, Kraków 2006.

Rodowska K., Na szali znaków. Czternastu poetów francuskich, Wrocław 2007.

Ruszar J. M. (red.), Dialog i spór. Zbigniew Herbert a inni poeci i eseiści, Lublin 2006.

Sioma R., Skończoność przedmiotów i niegotowość człowieka, [w:] Ruszar J. M. (red.), Dialog i spór. Zbigniew Herbert a inni poeci i eseiści, Lublin 2006.

Skoczek A. (red.), Literatura wspótczesna, Warszawa 2008.

Skrzypczak W., Myśl ucieleśniona i myśl imaginacyjna. Wymiary obrazowania w języku i zasady porządkujące, „Litteraria Copernicana" 2008, nr 2.

\section{Netografia}

http://www.philovive.fr/?2006/11/24/42-la-philosophie-de-la-guerre-prepare-t-elle-la-paix, 19.03.2011.

http://www.jean-pierre-faye.net/bibliographie/\#poemes, 19.03.2011.

http://pretexte.perso.neuf.fr/PretexteEditeur/ancien-site/revue/entretiens/discussions-thematiques_poesie/discussions/ jean-marie-gleize.htm, 19.03.2011.

http://www.zonesdattraction.org/spip.php?article27, 19.03.2011.

\section{Słowa kluczowe}

literatura XX wieku, II wojna światowa, komparatystyka literacka, modalność percepcyjna.

19 A. Kaliszewski, Zbigniew Herbert, [w:] A. Skoczek (red.), Literatura wspótczesna, Warszawa 2008, s. 315. 


\section{STResZcZenie}

Proponowane w niniejszym szkicu zestawienie twórczości polskiego i francuskiego autora ogranicza się do ukazania i przybliżenia zagadnienia odnajdywania tożsamości w powojennej rzeczywistości. Dwa odrębne, całkowicie odmienne doświadczenia wydają się pozornie na tyle odległe, oddzielone faktami, że nie sposób uczynić z nich doświadczeń zbieżnych. Niemniej jednak poetyckie widzenie wojennych przeżyć, starań o przetrwanie w świecie niespodziewanie „wywróconym", ze zmienionymi wartościami, danymi nagle á l'envers zdaje się zbliżać obu autorów.

Przedmiotem analizy jest nie tylko świat wartości konstruowany przez obu autorów. W tekście mowa również o językowym ujęciu rzeczywistości, przestrzeni. Taki sposób ukazywania, a jednocześnie obserwowania i kontrolowania przestrzeni służy jednocześnie „oswajaniu” świata, przedmiotów oraz uzasadnianiu istnienia człowieka w zrujnowanej powojennej rzeczywistości. Istotną rolę odgrywa tutaj również somatyczna sfera człowieczeństwa będąca jak gdyby kluczem do zrozumienia ontologicznej tajemnicy ludzkiego ciała.

Wszystkie te cechy, wraz z emocjonalnym „ciężarem" słowa, nad którym Faye i Herbert wydają się jednakowo czuwać, wyznaczają liczne i ważne podobieństwa pomiędzy poetykami obu twórców.

\section{“WAR IS A BODY BUT OVERTURNED" \\ LOOKING FOR IDENTITY IN THE POST-WAR WORLD EXEMPLIFIED BY \\ La Guerre trouvée Written by Jean-Pierre Faye \\ and Hermes, DOG aND STAR Written by Zbigniew Herbert}

\section{Keywords}

20th century literature, The Second World War, comparative literature, perceptual modality

\section{Summary}

This article is a short overview of the creative works of both Polish and French authors, which shows the issue of shaping identity in the post-war reality. The two separated, completely different experience seem to be so remote and separated by the facts that it could be impossible to make them similar. However, the poetic vision of war experience, striving for surviving in the suddenly "overturned" world, with changed values, given á l'envers seem to make both authors more similar.

The subject of the analysis is not only the world of values constructed by both authors but also the image of reality, of space, created by and through language. Such method of creating the images by observing and controlling, serves "softening" the world, the objects and proving the right to human existence in a ruined post-war reality. Somatic aspect of human beings plays here an important role, being a kind of key to understanding the ontological secret of human body.

All those features with the emotional "burden" of the words, which seems to be important for both authors, give a proof of similarity of the poetics of both artists. 